
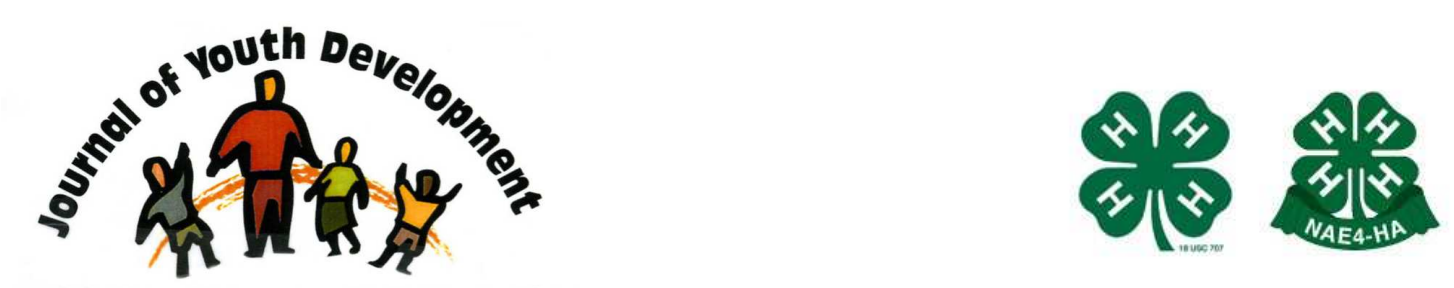

Bridging Research \& Practice

\title{
The Influence of Competitive Personality Orientation on Adolescent Emotional Intelligence
}

\author{
Scott D. Scheer \\ Department of Human \& Community Resource Development \\ \& OSU Extension \\ The Ohio State University \\ Columbus, $\mathrm{OH}$ \\ scheer.9@osu.edu
}

Nicholas Harrod

George Washington University

Washington, D.C.

Kristi S. Lekies

School of Environment and Natural Resources

\& OSU Extension

The Ohio State University

Columbus, $\mathrm{OH}$

lekies.1@osu.edu 


\title{
JOURNAL OF YOUTH DEVELOPMENT \\ bridging research and practice

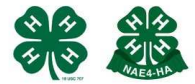

Volume 7, Number 2, Summer 2012

Article 120702FA001

\section{The Influence of Competitive Personality Orientation on Adolescent Emotional Intelligence}

\author{
Scott D. Scheer, Nicholas Harrod and Kristi S. Lekies
}

\begin{abstract}
Emotional intelligence (EI) is related to life success and everyday social interactions. The extent to which competitive personality orientation (CPO) may influence emotional intelligence among adolescents is unknown. The objective of this investigation was to determine the relationship between adolescent competitive personality orientation and emotional intelligence and if competitive personality orientation predicts emotional intelligence while controlling for demographic variables. Participants were 200 students (91 females, 109 males, $M$ age $=17.24$ years) from three Midwestern high schools. An inverse relationship was discovered between competitive personality orientation and emotional intelligence. Higher competitiveness was associated with lower levels of EI and this relationship was maintained when demographic variables were statistically controlled. As well, females scored significantly higher for EI and lower for competitive orientation than males. The findings potentially have implications for youth organizations to consider the level of emphasis placed on competitive programming and for including activities whereby youth work cooperatively with each other for promoting EI development.
\end{abstract}

\section{Introduction}

There has long been a need to understand why individuals similar in intellectual cognitive ability differ in being successful at life (i.e., work, relationships, income, etc.). Why do many cognitively intelligent people struggle in life, while less cognitively intelligent individuals prosper and succeed? Do particular personality orientations influence emotional intelligence (EI) development? Underlying these questions about EI is whether competitive personality orientation (CPO) may contribute to the formation of EI or put individuals at risk for lacking emotional life skills.

Emotional intelligence has been defined in a number of ways. One definition of EI by Goleman, who popularized EI in 1995 with his book by the same name, denotes it as the combination of 
factors that allow a person to feel, be motivated, regulate mood, control impulse, persist in the face of frustration, and thereby succeed in day-to-day living (1995). EI is a concept with its origins connected to social intelligence (Rehfeld, 2002) and is viewed as a "different way of being smart" (Goleman, 1995). EI has also been identified as the ability to monitor one's own and others' feelings and emotions, to discriminate among them, and to use this information to guide one's thinking and actions (Salovey \& Mayer, 1990). In other words, it means the ability to perceive, use, understand, and manage emotions (Mayer \& Salovey, 1997; Salovey \& Grewal, 2005).

Emotions play a vital part in the ways humans interact with each other and perform in home, school, and work settings; therefore, the need to understand emotions and EI is important. EI has been shown to be relevant to many aspects of life and the role it plays in the interactions and decisions in daily life. Research findings indicate positive relationships between EI and leadership (Bertges, 2002), achievement test scores (Fannin, 2002), and problem solving (Schutte, Schuettpelz, \& Malouff, 2000).

In a different stream of research, hundreds of studies have been analyzed comparing the effects of cooperative, competitive, and individualistic environments with people of all ages (D.W. Johnson, \& R.T. Johnson, 1989, 1992). It was found that cooperative learning produces higher achievement, social skills through positive relationships, and healthier psychological adjustment (self-esteem) than competitive or individualistic environments.

Competitive environments for children can be challenging as they can have a difficult time mentally understanding winning and losing. Especially when children lose at something, how they feel about themselves and reality often merge as they relate negative feelings of their selfworth and identity (Minuchin, 1977). Competition is almost always connected to external awards and approval. Whether children win or lose in competitive settings they start to form an extrinsic identity which is a fragile foundation for their developing self-concepts. Studies have linked extrinsic motivation with competition (reward driven, playing only to win, ego oriented) and intrinsic motivation with cooperation (mastery driven, self-determined, task oriented) (Amabile \& Hennessey, 1992; Chandler \& Connell, 1987). Even though much research has been conducted in the area of competition and cooperation, the connection between EI and competition has not been investigated.

There is evidence in the social value orientation literature that individuals can be categorized as prosocial, individualistic, or competitive (Van Lange, Otten, De Bruin, \& Joireman, 1997). According to this approach, prosocials get along with others which benefits those they work with and themselves. Individualists are concerned about what primarily helps them, and competitors base their abilities and achievements in comparison to and at the expense of others. Studies have indicated that social values orientations are related or predictive of helping behaviors, decision making, and interpersonal relationship dynamics (Beggan, Messick, \& Allison, 1988; McClintock \& Allison, 1989; van Prooijen, et al., 2008). It is unclear how social value orientations develop (e.g., nature/biological, child-parent attachment, parenting, peer relationships, social interaction history), especially in relationship to other dimensions of human development such as EI.

Horney (1937) hypothesized that a strong desire to compete and win at all costs was unhealthy for human development and functioning. More recently, Ryckman, Hammer, Kaczor, and Gold (1990) found through their development of a hypercompetitive attitude scale, that strongly competitive individuals were less psychologically healthy. These researchers have also reported 
hypercompetitive individuals expressed a lack of social concern for others and for treating them with respect (Ryckman, Libby, Borne, Gold, \& Lindner, 1997). Since EI is related to positive psychological functioning and an intrinsic sense of self, CPO may negatively influence EI, but the extent to which CPO may be related to EI among adolescents is unknown.

The objectives of this investigation were to determine the relationships of competitive personality orientation to adolescent emotional intelligence and to ascertain whether these relationships continue to exist when demographic variables (i.e., sex, age, location, mother's education, father's education, and household income) are statistically controlled. We hypothesized that youth who have a competitive personality will have lower levels of EI. A greater understanding of CPO and EI can be beneficial to youth organizations, which strive to develop opportunities that contribute to positive social, learning, and life skill outcomes, such as improved self-confidence and improved relationships with others (Durlak \& Weissberg, 2007; Little, Wimer, \& Weiss, 2008). As a result, program leaders can more intentionally plan the types of activities that best meet the developmental needs of youth.

\section{Methods}

\section{Sample and Procedure}

The sample for this study consisted of high school aged students ages 16-19 from three Midwestern high schools. Two of the schools were in rural public districts and the third was a private high school in a suburb of a Midwestern city. All three of the schools had diverse socioeconomic compositions. Before data collection started, the research procedures were approved by the university's institutional review board, and written consent was obtained from youth and parent(s) if participants were younger than 18 years old. Questionnaires were distributed to students in their homerooms, rather than by subject areas, to ensure a more diverse sample. Collected data were entered and analyzed using SPSS software. This research is part of a larger study which reported on demographics and EI (Harrod \& Scheer, 2005).

Of a possible 275 respondents, 200 (73\%) returned the consent forms and participated in the study by completing the assessment. There were 91 females (46\%) and 109 males (54\%) in the study with an average age of 17.2 years. The sample was almost evenly split for location of residence (50.8\% urban, $49.2 \%$ rural). Educational levels of parents ranged from some high school to completion of graduate school. The majority of youth reported parents had either a high school diploma (mothers $44.3 \%$, fathers $44.0 \%$ ) or a college degree (mothers $28.4 \%$, fathers $26.9 \%$ ). Household income was reported in the following categories: less than $\$ 20,000$ $(6.6 \%), \$ 20,000-39,999(11.4 \%), \$ 40,000-\$ 59,999(29.3 \%), \$ 60,000-79,999(19.8 \%)$, and $\$ 80,000$ or more (32.9\%). Ethnicity was not examined since most participants were of white/non-Hispanic origin.

\section{Instrument}

The questionnaire consisted of three sections: 1) demographics, 2) EI assessment, and 3) competitive-orientation scale. Demographics assessed respondents' age, sex, household income, parents' levels of education, and location of residence. Guidelines for income brackets and classification of residence were obtained from the U.S. Census Bureau (2008).

EI was measured with the Bar-On Emotional Quotient Inventory Youth Short Version (Bar-On EQ-i:YV(S)). It was developed by Bar-On and Parker (2000) and purchased from Multi-Health Systems (MHS). EI as measured by this instrument is defined as the perceived abilities related to understanding oneself and others, relating to people, managing emotions, and adapting to 
changing environmental demands (Bar-On \& Parker, 2000). A critical review of EI was conducted by Conte (2005) who identified three main approaches for measuring EI: self-report personality-based approaches, informant strategies, and ability-based assessments.

Furthermore, Conte (2005) indicated four major EI measures: Emotional Competence Inventory (self-report personality based), Bar-On and Parker's Emotional Quotient Inventory (self-report personality based), Multifactor EI scale (ability based), and Mayer-Salovey-Caruso EI Test (ability based). Since this study examined EI in regards to competitive personality orientation, Bar-On and Parker's (2000) self-report, personality emotional quotient inventory (youth version) was utilized.

The Bar-On EQ-i:YV(S) consists of 30 items with a choice of four responses ranging from "Not True of Me (Never, Seldom)" to "Very Much True of Me (Very Often)." Items include: "I care what happens to other people", "I get angry easily" (reverse score), and "I am good at solving problems." Validity for the Bar-On EQ-i:YV(S) has been established through national normative studies (Bar-On \& Parker, 2000). Concurrent validity is also evident with personality assessments such as the Connors-Wells Self Report Scale, the Connors Parent Rating ScaleRevised, and the Children's Depression Inventory (CDI) (Bar-On \& Parker, 2000). The internal consistency and reliability of the instrument for this study was measured using Cronbach's alpha $(a=.84)$. A total EI score was computed for each participant $(M=68.29, S D=8.02)$.

A modified version of the hypercompetitive attitude scale (Ryckman, Hammer, Kaczor, \& Gold, 1990) was used to determine one's disposition toward competition. The original scale consisted of 26 items, but was reduced to 10 items to improve clarity and decrease the time to take the survey. The items responses ranged on a four-point scale from $1=$ "never, seldom," to $4=$ "very often" with several items reversed scored to control response bias. Example items include: "I compete with others even if they are not competing with me", "Losing in competition has little effect on me" (reverse scored), and "I find myself turning a friendly game or activity into a serious contest or conflict."

Items were summed with higher values indicting a competitive personality orientation $(M=22.51, S D=4.91)$. Psychometric properties of reliability and validity have been established (Ryckman, Hammer, Kaczor, \& Gold, 1990). The internal consistency and reliability of the scale for this study was .78 using Cronbach's alpha.

\section{Results}

Correlation analysis was conducted in order to determine relationships between emotional intelligence and competitive personality orientation. Next, Analysis of Variance was used to examine possible differences between EI, CPO, and the demographic variables of age, sex, location of residence, parent's level of education, and household income. Finally, the demographic variables and measure of CPO were used as independent variables in a regression model with EI as the dependent variable.

Pearson correlation tests showed a negative relationship between EI and CPO $(r=-.24, p<.001)$; as EI scores increased, CPO decreased. No differences in levels of EI were found based on age or location of residence. For EI and sex, female EI scores $(M=69.73, S D=7.59)$ were significantly higher, than the male scores $(M=67.08, S D=8.21), t(198)=2.35, p=.02$.

EI scores increased with parent education levels. As significant differences in overall mean EI scores were found based on educational level for mothers, $f(4,188)=3.21 ; \mathrm{p}=.014$, and 
fathers, $\Re(4,187)=7.99 ; p=.000$. Subgroup analysis using Scheffe post hoc comparisons indicated no significant differences within the subgroups for mothers' education, although the differences between high school graduates and those who completed graduate school approached significance at $p=.08$. For father's education, one significant difference was found between EI scores for high school graduates' and those who completed graduate school, $p=.002$. The level of education, "some high school," was not included because of its minimal cell size, $n=3$.

For competitive personality orientation and demographic variables, the only variable with significant differences was sex. Males $(M=23.58, S D=4.94)$ had higher CPO scores, than females $(M=21.24, S D=4.60), t(198)=3.46, p=.001$. CPOs for the participating adolescents were similar regardless of age, parent education, location of residence, and household income.

Regression analysis revealed that the model significantly predicted adolescent emotional intelligence, $f(7,150)=6.49, p=.000$. Significant relationships $(p<.05)$ were found for competitive orientation ( $\beta=-.26)$, sex (female, $\beta=-.16$ ), and father's education (higher levels, $\beta=.22$ ). The regression model explained $20 \%$ of the variance. See Table 1.

\section{Table 1}

Summary of Linear Regression Analysis for the Emotional Intelligence Dependent Variable

\begin{tabular}{|c|c|c|c|c|}
\hline \multirow[t]{2}{*}{ Model } & \multicolumn{2}{|c|}{$\begin{array}{l}\text { Unstandardized } \\
\text { coefficients }\end{array}$} & \multirow{2}{*}{$\begin{array}{c}\text { Standardized } \\
\text { coefficients } \\
\text { Beta }\end{array}$} & \multirow[b]{2}{*}{$\mathrm{t}$} \\
\hline & Beta & SE & & \\
\hline (Constant) & 60.42 & 15.83 & & $3.82 * * *$ \\
\hline Competitive orientation & -.39 & .11 & -.26 & $-3.43 * * *$ \\
\hline Sex & -2.54 & 1.27 & -.16 & $-2.00 *$ \\
\hline Age & .45 & .91 & .04 & .50 \\
\hline Residence & -.15 & .56 & -.02 & -.27 \\
\hline Mother's education & .61 & .65 & .09 & .94 \\
\hline Father's education & 1.45 & .65 & .22 & $2.24 *$ \\
\hline Household income & .96 & .57 & .15 & 1.70 \\
\hline
\end{tabular}

Note. $\mathrm{n}=200, \mathrm{R}^{2}=.23$, Adjusted $\mathrm{R}^{2}=.20, \mathrm{SE}=7.06, * \mathrm{p}<.05, * * \mathrm{p}<.01, * * * \mathrm{p}<.001$

\section{Discussion}

While there have been critical studies about emotional intelligence and how it is defined and measured (Davies, Stankov, \& Roberts, 1998; Roberts, Zeidner, \& Matthews, 2001), other investigations (Caruso, Mayer, \& Salovey, 2002; Conte, 2005; Salovey \& Grewal, 2005) have provided evidence to support further studies of EI and its potential implications for understanding human abilities and functions. The findings in this article add to the research literature for EI in relation to CPO.

The findings support the study's hypothesis. An inverse relationship was discovered between adolescent CPO and EI. In other words, adolescents with a competitive-personality orientation reported lower levels of EI. While controlling for demographic variables, competitive-oriented 
youth were predictive of lower EI outcomes. In addition, females and increasing father's education were significant EI predictors. The independent variables accounted for $20 \%$ of the variance in the full model. For social science research, this amount of variance explained is noteworthy. In comparison, IQ accounts for $16 \%$ - $54 \%$ of the variance for academic achievement (Rohde \& Thompson, 2007). These results are a start for understanding EI formation and relationships of EI with personality traits such as competitiveness.

By studying EI with individuals who are in transition from childhood to adulthood, it is possible to capture a glimpse of the formative elements of EI development. Because EI plays an integral role in interactions with others and in success in day-to-day living (Goleman, 1995), examining adolescent EI may help to further understand the areas of life influential to EI formation as youth begin to interact and play an active role in the adult world.

Variables such as sex, age, and location of residence have been connected to emotional processes and development during adolescence (Conger \& Elder, 1994, 2000; Fernandez \& Rodriguez, 2003; Ge, Conger, \& Elder, 2001). In addition, investigations of competitive and cooperative environments have found that individuals in competitive settings had poorer selfconcepts and more negative interpersonal relationships (D.W. Johnson, \& R.T. Johnson, 1987). Social interaction settings (e.g., cooperative or competitive) may be a key contributor to how individuals develop particular personality orientations such as prosocial/cooperative, individualistic, and competitive (Van Lange, et al., 1997). These relationships and the present findings demonstrate the need to further examine EI, not only in terms of CPO, but also how individuals with a prosocial/cooperative orientation may influence EI.

Limitations for this study include the mostly white/non-Hispanic sample which would not have allowed appropriate data analysis for race and ethnicity comparisons. The sample size may have been reduced because of required consent forms. Another limitation is that EI has been measured in different ways such as ability based and self-report, resulting in inconsistencies for assessing EI (Gowing, 2001). An ability and competency based approach to understanding EI has been argued as most useful for measuring EI (Salovey, Detweiler-Bedell, B.T., DetweilerBedell, J.B., \& Mayer, 2008) rather than self-reported personality based EI measures which are reported to lack discriminant validity with other personality dimensions (Conte, 2005).

Additional studies of EI and CPO should go beyond self-report personality tools such as the one used in this study and include ability-based approaches as recommended by Salovey, et al. (2008).

\section{Conclusions and Implications}

This is the first study to examine the influence of competitive personality orientation (CPO) to adolescent emotional intelligence (EI). Multiple areas of life success and characteristics have been linked to EI, and this study has demonstrated that CPO is also related to EI. The findings have implications for families and youth-serving organizations as they consider the type of youth programming for their children's involvement. The results suggest that non-competitive environments might be more conducive to EI development. In addition, youth development programs may want to consider placing less emphasis on competition, by increasing activities in which youth work cooperatively with each other. Additional research will help to further understand the processes of EI. 


\section{References}

Amabile, T.M., Hennessey, B.A. (1992). The motivation for creativity in children. In A.K. Boggiano \& Pittman, T.S. (Eds.) Achievement and motivation: A social-developmental perspective, (54-74). New York: Cambridge University Press.

Bar-On, R., \& Parker, D.A. (2000). Bar-On Emotional Quotient Inventory: Youth Version, Technical Manual. North Tonawanda, New York: Multi-Health Systems.

Beggan, J.K., Messick, D.M., \& Allison, S.T. (1988). Social values and egocentric bias: Two tests of the "might over morality" hypothesis. Journal of Personality and Social Psychology, 55, 606611.

Bertges, W.M. (2002). The relationship between stressful life events and leadership in adolescents with an emphasis on explanatory styles and emotional intelligence. Dissertation Abstracts International, 62, 11-B.

Caruso, D.R., Mayer, J.D., Salovey, P. (2002). Relation of an ability measure of emotional intelligence to personality. Journal of Personality Assessment, 79(2), 306-320.

Chandler, C.L., \& Connell, J.P. (1987). Children's intrinsic, extrinsic and internalized motivation: A developmental study of children's reasons for liked and disliked behaviors. British Journal of Developmental Psychology, 5, 357-365.

Conger, R.D., \& Elder, G.H. Jr. (Eds.). (1994). Families in troubled times. New York: Aldine DeGruyter.

Conger, R.D., \& Elder, G.H. Jr. (2000). Children of the Land: Adversity and Success in Rural America. Chicago: University of Chicago Press.

Conte, J.M. (2005). A review and critique of emotional intelligence measures. Journal of Organizational Behavior, 26, 433-440.

Davies, M., Stankov, L., \& Roberts, R.D. (1998). Emotional intelligence: In search of an elusive construct. Journal of Personality and Social Psychology, 75(4), 989-1015.

Durlak, J.A., \& Weissberg, R.P. (2007). The impact of after-school programs that promote personal and social skills. Retrieved from the Collaborative for Academic, Social, and Emotional Learning Web site: http://www.casel.org/downloads/ASP-Full.pdf

Fannin, B.E. (2002). The contributions of emotional intelligence to academic achievement and production. Dissertation Abstracts International, 62, 12-A.

Fernandez, M.L., \& Rodriguez, Y. (2003). Age and sex differences in self-esteem among Spanish adolescents. Psychological Reports, 93(3), 876-878.

Ge, X., Conger, R.D., \& Elder, G.H. (2001). Pubertal transition, stressful life events, and the emergence of gender differences in adolescent depressive symptoms. Developmental

Psychology, 373), 404-417. 
Goleman, D. (1995). Emotional Intelligence. New York: Bantam Books.

Gowing, M.K. (2001). Measurement of individual emotional competence. In C. Cherniss, \& D. Goleman (Eds.), The emotionally intelligent workplace: How to select for, measure, and improve emotional intelligence in individuals, groups, and organizations (pp. 83-131). San Francisco, CA: Jossey-Bass.

Harrod, N., \& Scheer, S.D. (2005). An exploration of adolescent emotional intelligence in relation to demographic characteristics. Adolescence, 40(159), 503-512.

Horney, K. (1937). The neurotic personality of our time. New York: Norton.

Johnson, D.W., \& Johnson, R.T. (1987). Research shows benefits of adult cooperation. Educational Leadership, 45(3), 27-30.

Johnson, D.W., \& Johnson, R.T. (1989). Cooperation and competition: Theory and research. Ednia, MN: Interaction Book Inc.

Johnson, D.W., \& Johnson, R.T. (1992). Preparing children to live in an interdependent world. In A. Combs (Ed.), Cooperation: Beyond the age of competition, (pp. 193-202). Philadelphia, PA: Gordon and Breach.

Little, P.M.D., Wimer, C., \& Weiss, H.B. (2008). After-school programs in the $21^{\text {st }}$ century: Their potential and what it takes to achieve it. (Issue Brief \#10). Retrieved from the Harvard Family Research Project Web site: http://www.hfrp.org/publications-resources.

Mayer, J.D., \& Salovey, P. (1997). What is emotional intelligence? In P. Salovey \& D. Sluyter (Eds.), Emotional development and emotional intelligence: Educational implications (pp. 3-31). New York: Basic Books.

McClintock, C.G., \& Allison, S. (1989). Social value orientation and helping behavior. Journal of Applied Social Psychology, 19, 353-362.

Minuchin, P. (1977). The middle years of childhood. Monterey, CA: Brooks Cole.

Rehfeld, R.E. (2002). Organizational trust and emotional intelligence: An appreciative inquiry into the language of the twenty-first century leader. Dissertation Abstracts International, 62, $11-A$.

Roberts, R.D., Zeidner, M., \& Matthews, G. (2001). Does emotional intelligence meet traditional standards for an intelligence? Some new data and conclusions. Emotion, 1, 196-231.

Rohde, T.E., \& Thompson, L.A. (2007). Predicting academic achievement with cognitive ability. Intelligence, 35, 83-92.

Ryckman, R.M., Hammer, M., Kaczor, L.M., \& Gold, J.A. (1990). Construction of a hypercompetitive attitude scale. Journal of Personality Assessment, 55(3\&4), 630-639.

Ryckman, R.M., Libby, C.R., Borne, B., Gold, J.A., \& Lindner, M.A. (1997). Values of hypercompetitive and personal development competitive individuals. Journal of Personality Assessment, 69(2), 271-283. 
Salovey, P., Detweiler-Bedell, B.T., Detweiler-Bedell, J.B., \& Mayer, J.D. (2008). Emotional intelligence. In M. Lewis, J. M. Haviland-Jones, \& L. F. Barrett (Eds.), Handbook of Emotions (pp. 533-547). New York, NY: Guilford.

Salovey, P., \& Grewal, D. (2005). The science of emotional intelligence. Current Directions in Psychological Science, 14(6), 281-285.

Salovey, P., \& Mayer, J.D. (1990). Emotional intelligence. Imagination, Cognition, and Personality, 9, 185-211.

Schutte, N.S., Schuettpelz, E., \& Malouff, J.M. (2000). Emotional intelligence and task performance. Imagination, Cognition \& Personality, 20 (4), 347-354.

U.S. Census Bureau. (2008). Data access tools. Retrieved December 12, 2008, from http://www.census.gov/main/www/access.html.

Van Lange, P.A.M., Otten, W., De Bruin, E.M.N., \& Joireman, J.A. (1997). Development of prosocial, individualistic, and competitive orientations: Theory and preliminary evidence. Journal of Personality and Social Psychology, 73(4), 733-746.

van Prooijen, J.W., De Cremer, D., van Beest, I., Stahl, T., van Dijke, M., \& Van Lange, P.A.M. (2008). The egocentric nature of procedural justice: Social value orientation as moderator of reactions to decision-making procedures. Journal of Experimental Social Psychology, 44(5), 1303-1315.

(C) Copyright of Journal of Youth Development $\sim$ Bridging Research and Practice. Content may not be copied or emailed to multiple sites or posted to a listserv without copyright holder's express written permission. However, users may print, download or email articles for individual use. 